\title{
The correlation analysis between urbanization phenomena and landuse change in Jakarta Special Province
}

\author{
Ratih Fitria Putri*, Aji Wijaya Abadi, and Utia Kafafa \\ Department of Environmental Geography, Faculty of Geography, Universitas Gadjah Mada, Indonesia
}

\begin{abstract}
The population of Jakarta Special Province continues to grow, most significantly after the $1960 \mathrm{~s}$, causing an increase of population density. The expanding population has been stimulating the development of the province, reflecting the rising demand of the population including land. Eventually, it influences the urbanization process and affects the dynamic of land utilization in Jakarta. This research is aimed to understand the correlation between urbanization phenomena and landuse change in Jakarta Special Province. The research implements the utilization of statistics, topographic map, and remote sensing data as well. The satellite image (Sentinel-2 Imagery) was used to determine urban area and non urban area which then describes the land urbanization level. During 3 years, Jakarta has experienced landuse change especially in residential area, green open space, and industrial area. In 2017, the urban area covered 76.89 percent of Jakarta's land and the coverage increased into 78.35 percent in 2019. Land urbanization level raised from 77.16 percent into 78.03 percent which means that roughly 77 percent to 78 percent of land in Jakarta has been urbanized.
\end{abstract}

\section{Introduction}

The phenomenon of urbanization is one of the problems that occur in big cities in Indonesia. The definition of urbanization according to [1] is a process of changing communities and regions in a non-urban area to become urban. This causes a specialization process for the use of certain spaces in an area, for example, the construction of settlements and various public supporting facilities for the community. Urbanization activities cause urban space patterns and structures to become increasingly complex [2]

The driver factors of urbanization can be related to the factors of migration. According to [3], there are four factors to consider in the study of population migration. These four factors are the area of origin, the factors found in the destination, the obstacles, and individual factors. The amount of migrants is influenced by the magnitude of the pull factors from the destination. The pull factors such as the rapid economic growth, education, and transportation that develops in a region. Thus, this condition attract residents of other regions to come. On the other hand, the natural growth rate also influences the process of urbanization. The more population there is, the more massive the development and causes of the urban process.

Recently, urbanization which occur in developing countries like Indonesia is remarkable. There are major causes that stimulate urbanization in developing countries such as capital investments, urban reclassification, and population mobility [4]. Jakarta is amongst regions in Indonesia that has been experiencing urbanization. The characteristics of urbanization in
Jakarta Special Province are marked by the increasing number of urban residents. Since the end of the $60 \mathrm{~s}$ to the present, the symptoms of urbanization in Jakarta have swelled from 10 million with relatively high population growth [1]. High incoming migration to Jakarta caused by the role of this province as the centre of the economy of the country [5].

Table 1 shows the population in Jakarta Special Province that has continued to increase from 2017-2019. According to [6] if the population growth rate $>2.5 \%$ means population migration is a major factor in influencing population growth. However, this province has a population growth rate of $1.19 \%(2010-2019)$ [7] so that the population increase is more dominantly influenced by natural growth factors

Table 1. Total population and population density.

\begin{tabular}{|c|c|c|c|}
\hline Year & $\mathbf{2 0 1 7}$ & $\mathbf{2 0 1 8}$ & $\mathbf{2 0 1 9}$ \\
\hline $\begin{array}{c}\text { Total } \\
\text { Population } \\
\text { (people) }\end{array}$ & 10374235 & 10467639 & 10572315,39 \\
\hline $\begin{array}{c}\text { Population } \\
\text { Density } \\
\text { (people/sq } \\
\mathrm{km} \text { ) }\end{array}$ & 15663.24 & 15804.27 & 15962.31 \\
\hline
\end{tabular}

The increase in population is directly linear to the increasing population density in this province. The urban land study cannot be completed from its role as the main input in urban development, where there is a transformation from land to the built environment [8]. The high level of urbanization and development has led

* Corresponding author: ratihfitria.putri@ugm.ac.id 
to a decline in environmental quality such as areas that were originally designated as catchment areas turned into residential land. Likewise, the suburbs in Jakarta are also developed into residential and industrial areas.

Another consequence of urban development in Jakarta is the phenomenon of land subsidence. This phenomenon occurs in Jakarta urban area continually [9]. Land subsidence can cause a disaster that will impact the building and road construction [10]. Hence, it will cause huge losses for all sectors. This research is aimed to understand the correlation between urbanization phenomena and landuse change in Jakarta Special Province.

\section{Methods}

\subsection{Location}

The area studied in the research focuses on Jakarta Special Province. Jakarta Special Province area includes five municipalities namely Jakarta Pusat, Jakarta Utara, Jakarta Timur, Jakarta Selatan and Jakarta Barat as well as one regency namely Kepulauan Seribu. The province has been labelled as a megacity since its population surpasses 10 million people with its remarkable change in population density and landuse [11]. It becomes consideration in choosing the province as a case study in this research with easily accessible data to visualize the phenomenon.

\subsection{Data}

The research implements the utilization of statistics, topographic map, and remote sensing data as well. Statistics were extracted from Jakarta in Figures 20182020 published by the Jakarta's Central Bureau of Statistics or Badan Pusat Statistik (BPS) Jakarta. The data obtained from the publication is population data in each municipality or regency and then processed for population projection. The topographic map was used to delineate landuse in Jakarta and landuse change analysis. The remote sensing data used in this research is Sentinel-2 Imagery. The satellite image was used to determine urban area and non urban area which then describes the land urbanization level.

\subsection{Research design}

The flowchart of research design is shown by Figure 1. The first step is collecting data from statistics and remote sensing. The second step is determining population projection and interpretation of landuse and urban area as well. The third step is conducted to identify landuse change area and the land urbanization level. The last step is analyzing descriptively the correlation of landuse change and urbanization with considering the population projection of Jakarta Special Province.

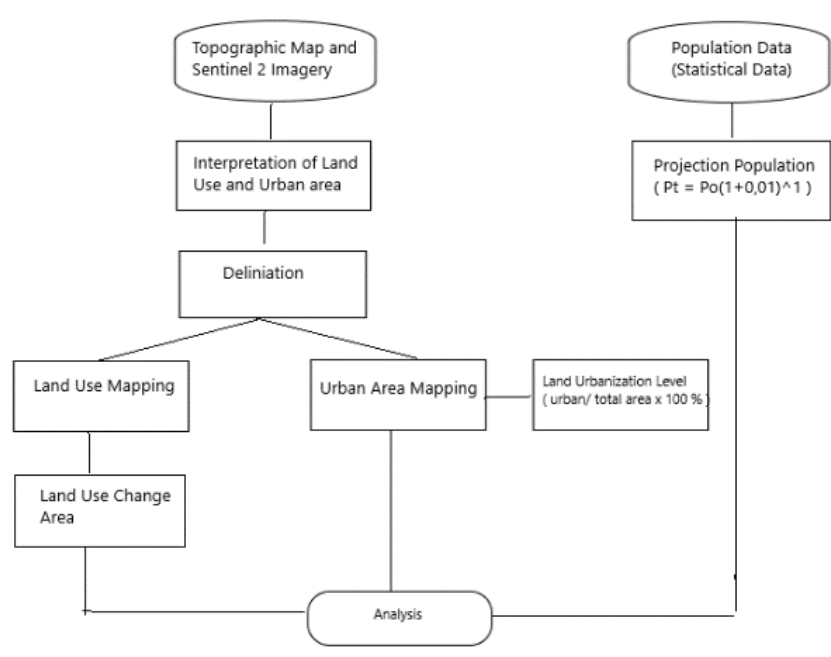

Fig. 1. Flowchart of research design.

\section{Results and discussions}

Jakarta Special Province has been experiencing significant population growth during the period of 20172019 as displayed on Figure 2. In 2017, the population of Jakarta has reached 10.37 million people which continued to grow, becoming 10.46 million people in 2018 and 10.57 million people in 2019. The most populous region in Jakarta is Jakarta Timur with a population of approximately 29 million people while the least populous region in Jakarta is Kepulauan Seribu which has a population of about 24 thousand people.

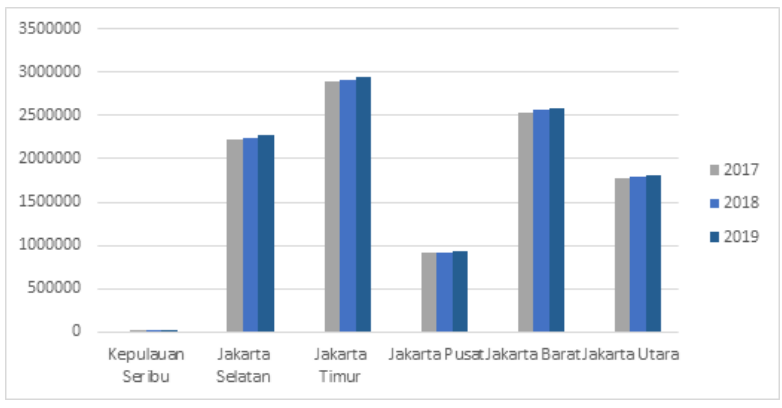

Fig. 2. Trend of population in DKI Jakarta 2017-2019 Flowchart of research design.

Source: BPS DKI Jakarta, 2018-2020 (Processed)

The burgeoning population in Jakarta causes an increase of population density which occurs in every region. Population density has a strong correlation with total population. Since there is no enlargement of every region in Jakarta, the total area keeps similar for all years. Thus, the higher the population, so does the population density. Figure 3 expresses the trend of population density in Jakarta from 2017 until 2019.

The figure shows different population density in every region in Jakarta. The mainland part of the province such as Jakarta Pusat, Jakarta Utara, Jakarta Timur, Jakarta Selatan and Jakarta Barat has higher population density than Kepulauan Seribu. These different values of population density can be classified into different classes. Based on the Center of Research and Settlement Development or Puslitbang Permukiman (2011) [12], a region is said to be less densely if the 
population density is below 15,000 people $/ \mathrm{km} 2$, to have moderate population density if the value range between $15,100-20,000$ people $/ \mathrm{km} 2$, to have high population density if the value range between 20,100-40,000 people $/ \mathrm{km} 2$, and to have very high population density if the value surpasses 40,000 people/ $\mathrm{km} 2$. According to the classification, Jakarta's population density is categorized in moderate level as its value during the period of 2017-2019 reaches 15,809.94 people/km2 The most densely populated region in Jakarta is Jakarta Barat whilst the less-densely populated region is Kepulauan Seribu.

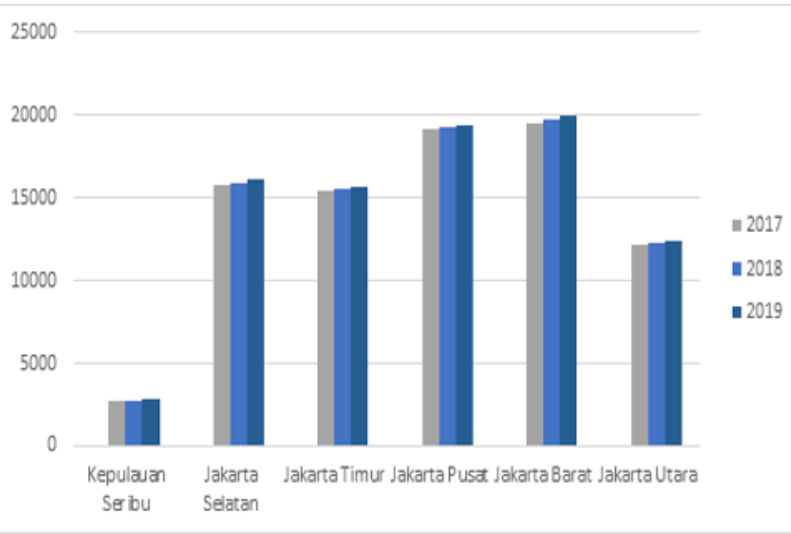

Fig. 3. Trend of Population Density in DKI Jakarta 2017-2019. Source: BPS DKI Jakarta, 2018-2020 (Processed)

Jakarta Barat has the third highest percentage of population. Besides the factor of population, other factors that cause high population density in Jakarta Barat can be reviewed through economic factors. In 2017 and 2018 Jakarta Barat occupied the highest contributor to Gross Regional Domestic Product of 6.48 percent and 6.39 percent [7]. This shows a better economic situation compared to the surrounding regions and it becomes a special attraction for migrants. Meanwhile, Kepulauan Seribu only occupies 1.41 percent of the total area in Jakarta Province. This region has the lowest density due to the geographical condition of the region which is a group of islands and a small population. The total number of islands is 110 small islands and the majority are uninhabited because some of them serve as tourist attractions.

The significant increase of population in Jakarta occurs dominantly in Jakarta's mainland. Economic and business activities, various job opportunities and abundance of facilities have attracted many migrants to come and settle in Jakarta. The most observable change corresponding influx of migration is the increasing demand of land for settlements. It means that the land allocation for settlements will increase and may conflict with other landuses. Moreover, more intensive and various economic and business activities in Jakarta has stimulated the expansion of industrial areas following economic shifting in Jakarta from agricultural sector to industrial and service sector. In short, the more built up area may cover and change the existing landuse in Jakarta Special Province. It results in landuse change issue that is most controlled by population dynamics.
Jakarta has a character that consists of a combination of landuse types from the most traditional, conventional to the hybrid type. The giant buildings are located face to face with villages and buildings [13]. There are landuse change observed based on the landuse map of Jakarta Special Province as shown in Figure 4 a,b,c. Generally, built-up area coverage increases overtime whilst the open space experiences differently.

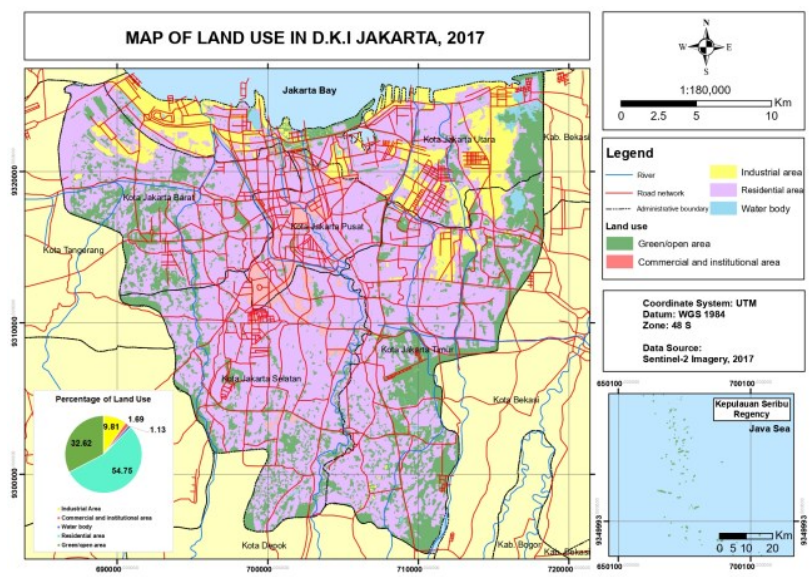

(a)

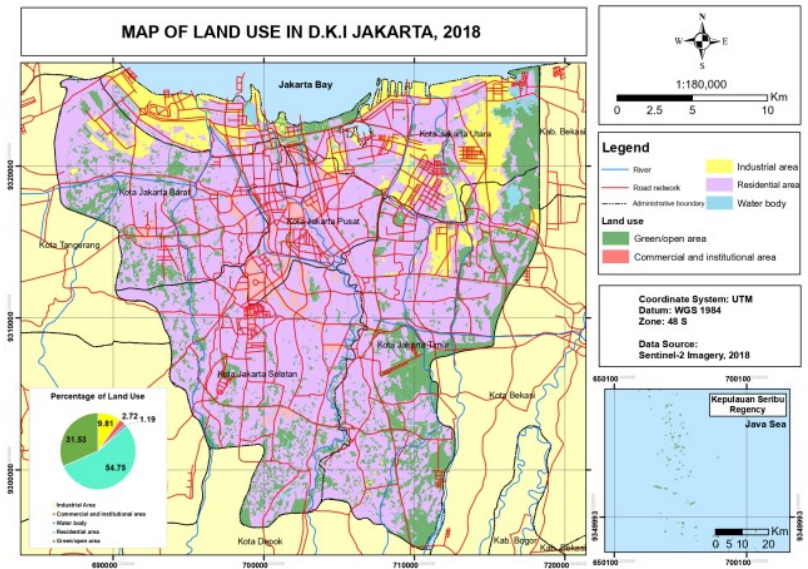

(b)

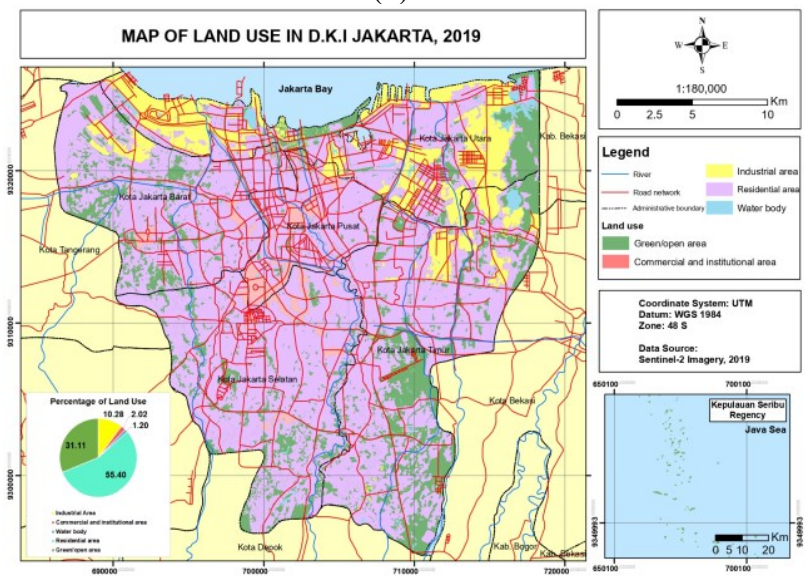

(c)

Fig. 4. Map of landuse in DKI Jakarta (a) 2017 (b) 2018 (c) 2019.

Source: Data Processing, 2020

Based on those maps, it can be seen that the residential area takes the most land proportion compared to other landuses. Residential area covers more than 50 percent of land in Jakarta. Green open space occupies 
roughly 30 per cent, industrial area uses 9 percent of Jakarta's land, and the rest is utilized for commercial area and institutional area as well as water body. During 3 years, Jakarta has experienced landuse change, especially in residential area, green open space, and industrial area. Residential area and industrial area landuse increase from 2017 until 2019 as the impact of increasing population in the province. Contrastly, the landuse for green open space in Jakarta experiences shrinkage as a consequence of increasing land demand for settlements and industries.

According to [14] green open spaces in the form of city parks are mostly taken over by residents or individuals as informal settlements, parking lots, or other business ventures. The existence of the green open spaces area is one of the efforts to overcome global warming. However, green open spaces are often sacrificed in developing urban infrastructure with the rapid rate of population growth [15].

Landuse change has led to the dynamics of the spatial pattern in Jakarta. Mainly, most open space has been being transformed into different landuse, especially for residential area and factories. It is possible to do so since the topography of Jakarta's land is relatively flat and gentle. Flat or gentle slopes are very suitable for settlements and industries. Flat land is easily utilized and has good availability of water resources which is a vital resource for the population and industrial activities. Moreover, the flatter the land, the development for accessibility is easier, which enables the region to activate strategic locations for settlements and industries. As the development continues, the more tendention of landuse conversion which is marked by the expanding of built-up area.

The extent of built up area in a region and increasing population density are amongst the characteristics of urbanization. Figure 5 presents the urbanization area in Jakarta from 2017 to 2019 , identified from satellite imagery. In 2017, the urban area covered 76.89 percent of Jakarta's land and the coverage increased into 78.35 percent in 2019. At the same time, non-urban area coverage was decreasing from 23.11 percent to 21.65 percent. The expansion of urban area from 2017 to 2019 indicates that there is development in terms of the builtup area which defines the physical characteristics of urban area. Jakarta Pusat is the only one region in Jakarta that its land is fully urbanized while the others not.

The extent of urban area makes the majority of the population exposed to the urban typical activities and eventually turns the population to have an urban lifestyle. It is assumed that the population living within the urban area is called the urban population. Urban population in Jakarta increased during the period 20172019 as shown on Figure 6. From the figure, it can be seen that the urban population in Jakarta has reached approximately 85 percent, showing that most of the population living in the urbanized area as explained in the prior paragraph.

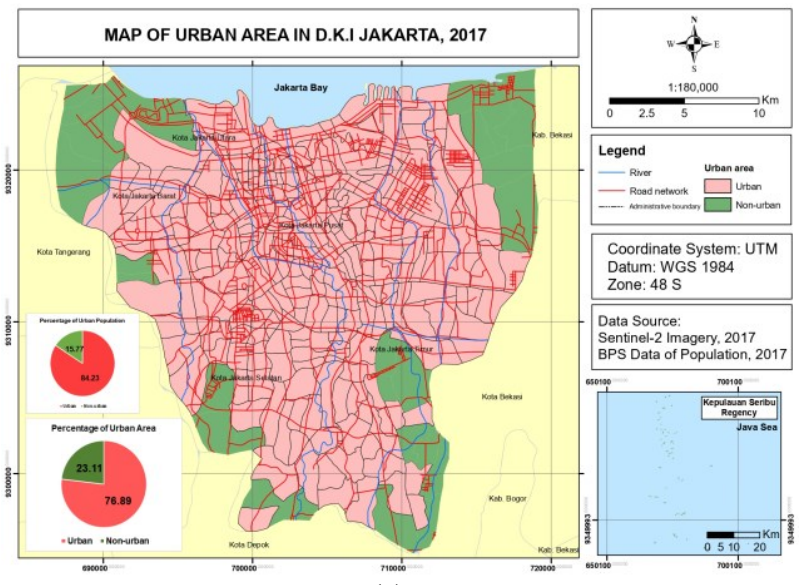

(a)

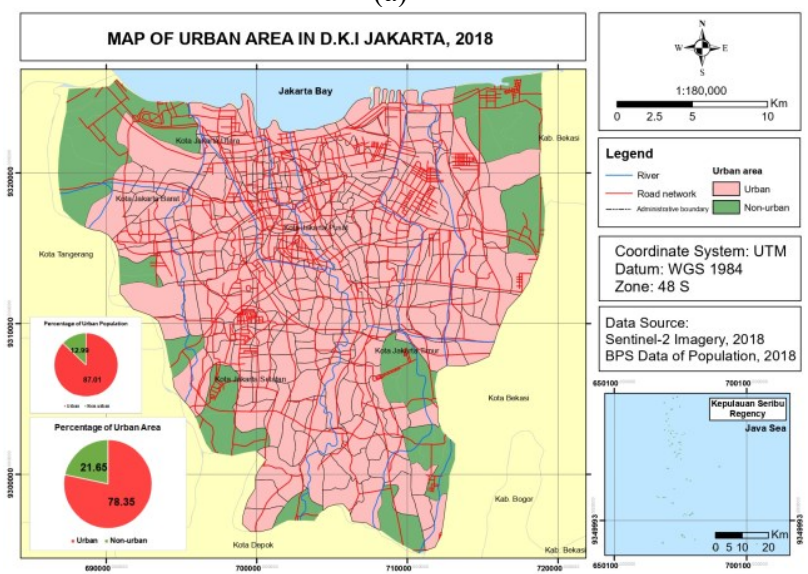

(b)

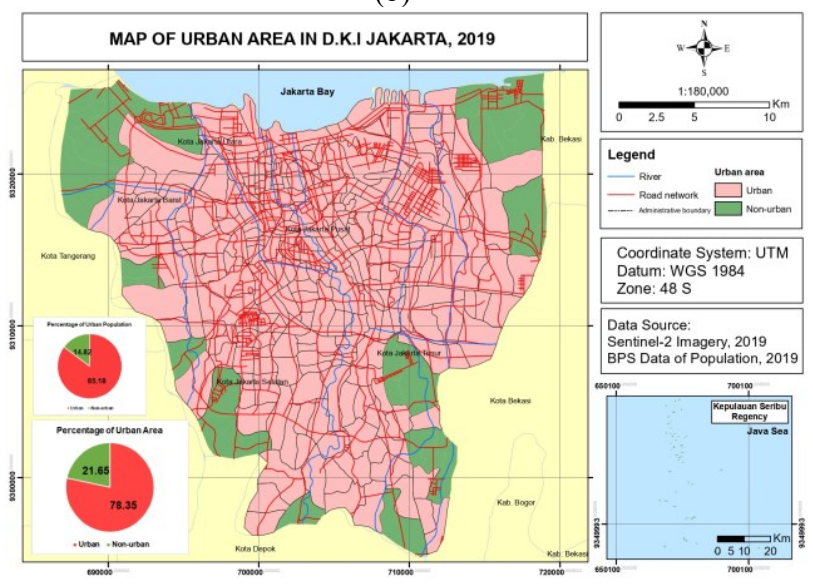

(c)

Fig. 5. Map of urban area in DKI Jakarta (a) 2017 (b) 2018 (c) 2019.

Source: Sentinel-2 Imagery, 2017-2019

The extension of built-up area and increasing urban population has shown that Jakarta is experiencing urbanization. The urbanization occured in Jakarta can be represented by land urbanization level. Land urbanization level is a ratio that expresses the urbanized area towards the total area in a certain region. Table 2 shows the land urbanization level in Jakarta from 2017 to 2019. During 3 years, land urbanization raised from 77.16 percent into 78.03 percent. It means that roughly 77 percent to 78 percent of land in Jakarta has been urbanized. 


\section{Conclusion}

During 3 years, Jakarta Special Province has experienced landuse change, especially in residential area, green open space, and industrial area. Residential area and industrial area landuse increase from 2017 until 2019 as the impact of increasing population in the province. Contrastly, the landuse for green open space in Jakarta experiences shrinkage as a consequence of increasing land demand for settlements and industries. In 2017, the urban area covered 76.89 percent of Jakarta's land and the coverage increased into 78.35 percent in 2019. At the same time, non-urban area coverage was decreasing from 23.11 percent to 21.65 percent. Land urbanization level raised from 77.16 percent into 78.03 percent. It means that roughly 77 percent to 78 percent of land in Jakarta has been urbanized. The expansion of urban areas from 2017 to 2019 is influenced by the increasing number of populations and also from the intensive development in various economic and business activities in Jakarta.

\section{References}

[1] F. R. Harahap, "Dampak Urbanisasi Bagi Perkembangan Kota Di Indonesia”, Society, vol. 1, no. 1, pp. 35-45(2013), in bahasa

[2] E. Sadewo and I. and P. Syabri, "Post-suburbia dan Tantangan Pembangunan di Kawasan Pinggiran Metropolitan: Suatu Tinjauan Literatur" Maj. Geogr. Indones., vol. 32, no. 2, pp. 130-141, 2018, in Bahasa

[3] E. S. Lee, “A Theory of Migration,” Demography, vol. 3, no. 1, pp. 47-57, 1996.

[4] S. Wilonoyudho, R. Rijanta, Y. T. Keban, and B. Setiawan, "Urbanization and regional imbalances in Indonesia,” Indones. J. Geogr., vol. 49, no. 2, pp. 125-132, 2017.

(c)

[5] R. F. Putri, S. Wibirama, S. R. Giyarsih, A. Pradana, and Y. Kusmiati, "Landuse change monitoring and population density analysis of Penjaringan, Cengkareng, and Cakung Urban Area in Jakarta Province," E3S Web Conf., vol. 76, 2019.

Table 2. Land urbanization level.

\begin{tabular}{|l|l|l|l|}
\hline \multirow{2}{*}{ Year } & \multicolumn{2}{|l|}{ Area (Km2) } & $\begin{array}{l}\text { Land } \\
\text { Urbanization } \\
\end{array}$ \\
\cline { 2 - 4 } & Urban & Non Urban & $\mathbf{( \% )}$ \\
\hline 2017 & 501.22 & 148.34 & 77.16 \\
\hline 2018 & 506.87 & 142.69 & 78.03 \\
\hline 2019 & 506.87 & 142.69 & 78.03 \\
\hline
\end{tabular}

Source: Data Processing, 2020

Although urbanization is not a new thing in Jakarta Province, the dynamics of urbanization continue to increase and are quite complex. Conscientious urban planning and involving various parties is needed to anticipate the various risks posed by this phenomenon.
[6] S. Bandiyono and K. F. Indrawardani, "Tinjauan Migrasi Penduduk Desa-Kota, Urbanisasi dan Dampaknya," Jurnal Kependudukan Indonesia, vol. V, no. 1. p. 14, 2010, in Bahasa

[7] BPS DKI Jakarta, DKI Jakarta dalam Angka Tahun 2020. Jakarta: Badan Pusat Statistik, 2020, in Bahasa

[8] A. M. Elmanisa, A. A. Kartiva, A. Fernando, R. Arianto, H. Winarso, and D. Zulkaidi, "Land Price Mapping of Jabodetabek, Indonesia," Geoplanning J. Geomatics Plan., vol. 4, no. 1, p. 53, 2016.

[9] R. F. Putri, L. Bayuaji, J. T. S. Sumantyo, and H. Kuze, "Terrasar-X DInSAR for land deformation detection in Jakarta Urban area, Indonesia," J. Urban Environ. Eng., vol. 7, no. 2, pp. 195-205, 2013.

[10] R. F. Putri, S. Wibirama, Sukamdi, and S. R. Giyarsih, "Population condition analysis of 
Jakarta land deformation area," IOP Conf. Ser. Earth Environ. Sci., vol. 148, no. 1, 2018.

[11] W. Mulyana, "Rural-Urban Linkages : Indonesia Case Study,” Dev. with Territ. Cohes., no. 126, pp. 1-34, 2014.

[12] P. Permukiman, "SNI 03-1733-2004," 2011. [Online]. Available: http://puskim.pu.go.id/Aplikasi/Kebutuhan_Rum ah/ref.php. [Accessed: 16-Apr-2020].

[13] J. Santoso, "Memahami Transformasi Urban di Asia: Belajar dari Kasus Jakarta," J. Tataloka, vol. 15, no. 2, p. 102, 2013. In Bahasa
[14] E. Permanasari and T. Liention, "Transformasi Makna dan Fungsi Ruang di RPTRA Kalijodo dalam Pergulatan Citra Kota Jakarta Transformasi Makna dan Fungsi Ruang di RPTRA Kalijodo dalam Pergulatan Citra Kota Jakarta," vol. 16, no. May, pp. 12-27, 2019. In Bahasa

[15] S. Subarudi and I. Samsoedin, "Kajian Kebijakan Hutan Kota: Studi Kasus Di Provinsi Daerah Khusus Ibukota Jakarta (DKI)," J. Anal. Kebijak. Kehutan., vol. 9, no. 2, pp. 144-153, 2012. In Bahasa 